\title{
O Buffer de Capital Contracíclico de Basileia Ill: uma Avaliação
}

\section{The Basel III Countercyclical Capital Buffer: an Assessment}

\author{
Guilherme Peres* \\ Luiz Fernando de Paula**
}

\begin{abstract}
Resumo: A regulação e supervisão do sistema financeiro tem sido recentemente um dos motivos de apreensão por parte das principais autoridades econômicas mundiais. A globalização, o processo de liberalização financeira e a consequente interconexão econômica entre países aumentaram o risco sistêmico, colocando a necessidade de marco regulatório e fiscalização mais eficientes. Assim, com a eclosão da crise norte-americana em 2008, o G-20 começou a atuar de forma mais ativa em prol da manutenção da higidez do sistema financeiro mundial. Para os bancos, o G-20 instruiu as principais instituições reguladoras como o Fundo Monetário Internacional (FMI), o Conselho de Estabilidade Financeira e o Comitê de Basileia (BCBS, sigla em inglês) a desenvolverem recomendações a fim de se solucionar o que pode ser considerado principal problema da regulação dos mercados: o fato do setor bancário ter um comportamento comprovadamente pró-cíclico. Diante de tal cenário, em dezembro de 2009, o Comitê publicou um documento que considerou uma série de medidas a fim de solucionar tal problema, entre estas estava a inclusão do buffer de capital contracíclico do novo marco regulatório proposto pelo Comitê (Basileia III). O objetivo do presente artigo é avaliar se a proposta de buffer contracíclico feito em Basileia III dá conta da pró-ciclicidade do setor, em particular no caso brasileiro.
\end{abstract}

Palavras-chave: Sistema financeiro. Crise financeira. Regulação financeira. Buffer contracíclico.

Abstract: The regulation and supervision of the financial system have been recently a prime concern of the global economic authorities. Globalization, the process of financial liberalization and consequent economic interconnection between countries have increased the systemic risk, and the need for a more efficient regulation. Thus, with the outbreak of the American crisis in 2008, the G-20 began to act more actively in favor of maintaining the soundness of the global financial system. For banks, the G-20 instructed the main regulatory institutions like the International Monetary Fund, the Financial Stability Board and the Basel Committee on Banking Supervision (BCBS) to develop recommendations to solve the main problem of the regulation of financial system: the fact that banking sector has a procyclical behavior. Faced with this scenario, in December 2009, the Committee published a document which considered a number of measures in order to solve this problem, among

\footnotetext{
* $\quad$ Doutorando em Economia pelo Programa de Pós-Graduação em Ciências Econômicas (PPGCE) da Universidade do Estado do Rio de Janeiro (UERJ). Professor assistente do Instituto de Matemática e Estatística (IME) da UERJ. Analista de projetos da Agência Brasileira da Inovação (Finep). E-mail: guimaperes@gmail.com

** Doutor em Ciência Econômica pela Universidade Estadual de Campinas (Unicamp). Professor titular da Faculdade de Ciências Econômicas (FCE) e do Instituto de Estudos Sociais e Políticos (IESP) da Universidade do Estado do Rio de Janeiro (UERJ). Pesquisador do CNPq. E-mail: luizfpaula@terra.com.br
} 
others the inclusion of a counter-cyclical capital buffer in the new regulatory framework proposed by the Committee, the Basel III. This paper aims at analyzing the proposal of countercyclical capital buffer and its applicability in the Brazilian banking system.

Keywords: Financial system. Financial crisis. Financial regulation. Counter-cyclical buffer

JEL Classification: G01; G28; E44.

\section{Introdução}

A regulação e supervisão do sistema financeiro sempre foram motivos de apreensão por parte das principais autoridades econômicas mundiais. A globalização, o processo de liberalização financeira e a consequente interconexão econômica entre os países aumentaram o risco sistêmico, colocando em questão a necessidade da existência de um marco regulatório e fiscalização mais eficaz do setor bancário. Assim, com a eclosão da crise norte-americana em 2008, o G-201 começou a atuar de forma mais ativa em prol da solidez do sistema financeiro mundial. Para os bancos, primeiros a serem afetados por esta nova política, o Grupo instruiu as principais instituições reguladoras como o Fundo Monetário Internacional (FMI), o Conselho de Estabilidade Financeira (Financial Stability Board - FSB) e o Comitê da Basileia (Basel Committee on Banking Supervision - BCBS) ${ }^{2}$ a desenvolverem recomendações a fim de se solucionar o considerado principal problema da regulação dos mercados: o fato do setor bancário ter um comportamento comprovadamente pró-cíclico.

Um modelo é considerado pró-cíclico quando está positivamente correlacionado com o ciclo econômico, por vezes até mesmo o alavancando, sendo assim o oposto de um comportamento contracíclico. Quando a crise eclodiu, o acordo vigente à época - Basileia II - acabou demonstrando tal característica, pois além de não assegurar a solidez do setor bancário, demonstrou exacerbar os ciclos econômicos. No caso de empréstimos bancários, Basileia II estabeleceu, de certa forma, que os bancos deveriam emprestar menos quando a economia arrefecer, o que reforçou os efeitos recessivos.

Diante desse cenário, em dezembro de 2009, o Comitê da Basileia publicou um documento que considerou uma série de medidas, a fim de solucionar tal problema, com quatro objetivos-chave: 1) suavizar qualquer característica pró-cíclica do requerimento de capital mínimo; 2) promover pro-

$\overline{1}$ Grupo formado pelos ministros de finanças e chefes dos bancos centrais das 19 maiores economias do mundo mais a União Europeia.

2 O BCSB é um fórum regular de cooperação sobre assuntos de supervisão regulatória, com o objetivo de contribuir para o entendimento das questões chaves regulatórias e aprimorar a qualidade da supervisão bancária no mundo. Para mais informações, ver http://www.bis.org/bcbs. 
visões com critérios mais prospectivos; 3) conservar capital como buffers ${ }^{3}$ a serem usados no momento de stress; e 4) proteger o setor bancário de períodos de crescimento excessivo do crédito. O terceiro objetivo originou o buffer de conservação de capital e o quarto o buffer de capital contracíclico do novo marco regulatório proposto pelo BCBS, chamado de Acordo de Basileia III.

Basileia III foi implantado no Brasil a partir de 2013. No entanto, esse novo acordo já nasce com um problema. Segundo alguns estudos - como Repullo e Saurina (2011) —, o buffer contracíclico que, como seu nome diz, teria como objetivo suavizar o ciclo econômico, faz exatamente o contrário. Dessa forma, este artigo objetiva avaliar as premissas de Basileia III com ênfase no buffer contracíclico e analisa sua aplicabilidade no caso brasileiro, inferindo seus resultados e suas consequências quanto à suavização do ciclo econômico. Em particular, avalia-se se a proposta de buffer contracíclico feito em Basileia III dá conta da pró-ciclicidade do setor bancário.

O presente artigo está dividido em cinco seções, além desta introdução: a seção 2 aborda de forma sucinta o sistema bancário e as causas da eclosão da crise financeira internacional, a seção 3 analisa os Acordos de Basileia I e II, a seção 4 examina o novo Acordo (Basileia III) com ênfase na metodologia do buffer contracíclico previsto em Basileia III e sua aplicação no setor bancário brasileiro e, finalmente, a seção 5 tece algumas considerações finais ao artigo.

\section{Sistema Bancário e a Crise Financeira Internacional}

A eclosão da crise norte-americana do subprime em 2007 foi considerada o estopim de uma cadeia de acontecimentos em toda a economia mundial, tendo efeitos sobre diversas nações. A referida crise teve como origem um profundo processo de globalização e desregulamentação financeira e de tentativas por parte das instituições financeiras em contornar a regulação através de processos inovadores.

A globalização financeira tem seus primórdios na década de 1960, quando houve o desenvolvimento do mercado de eurodólares, ${ }^{4}$ internacionalizado e extremamente desregulamentado, e tomou impulso a partir do colapso do sistema de Bretton Woods, que significou o fim do sistema de câmbio fixo e de controle de capitais. Nos anos 80 a adoção das políticas neoliberais de Thatcher no Reino Unido e de Reagan nos Estados Unidos acabou impondo a doutrina de livre-mercado ao mundo. Tais políticas deram início ao processo de desregulamentação e liberalização financeira nestes países e, consequentemente, no resto do planeta.

3 Requerimentos de capital que visam a aumentar a resiliência das instituições e suavizar os ciclos econômicos.

4 Depósitos em dólares efetuados por bancos localizados fora do território dos Estados Unidos. 
Na década de 1990, houve a continuidade do processo de liberalização financeira nos Estados Unidos, o que resultou na Lei de Modernização de Serviços Financeiros, a chamada Lei de Gramm-Billey-Leach. Após isso, o que se viu na década de 2000 foi um cenário extremamente positivo em que os juros eram baixos e a inflação das grandes economias mundiais estava sob controle. Esse cenário levou a uma enxurrada de liquidez internacional e a um acúmulo de ativos líquidos, muitos frutos do processo de inovação financeira. Nesse período houve estímulo à engenharia financeira e à maior alavancagem das instituições financeiras.

Paralelamente, outro fator que estimulou a globalização financeira foi o progresso tecnológico nos setores de comunicação e de informática, diminuindo os custos de transação envolvidos nos serviços financeiros, permitindo a atuação simultânea dos mercados financeiros e o processamento de informações online. Tais desenvolvimentos tecnológicos proveram a infraestrutura necessária para a expansão das atividades financeiras.

De acordo com Pereira (2011), dentro dessa nova lógica de funcionamento do sistema financeiro - da supremacia dos mercados frente ao Estado aliada à configuração atual do Sistema Monetário Internacional - vivenciou-se um momento cunhado por Minsky (1986) como money manager capitalism. Esse período foi marcado pela busca exacerbada dos lucros financeiros apoiada no desenvolvimento colossal de inovações tecnológicas. Outras medidas institucionais reforçaram esse processo de liberalização e, segundo Sidelsky (2009), três se destacam: (i) a revogação do Lei Glass-Steagall ${ }^{5}$ em 1999; (ii) a decisão do Governo Clinton em não regular os Credit Default Swaps ${ }^{6}$ (CDS); e (iii) a decisão de permitir que as instituições financeiras elevassem seus graus de alavancagem de $10 \%$ para $30 \%$ em 2009 .

Nesse contexto, Saddi (2010) sustenta que, à medida que o mercado passou a atuar em um ambiente cada vez mais desregulamentado, os limites entre as áreas bancária e financeira tornaram-se opacos, ocasionando a revogação da Lei Glass-Steagall. Carvalho e Kregel (2009) salientam que a promessa desse processo de liberalização era lançar uma nova era de investimentos crescentes e altas taxas de crescimento econômico ao redor do globo. Porém, o que se viu foi o desmantelamento das barreiras que separavam e protegiam segmentos específicos dos mercados financeiros, como o setor bancário comercial e as atividades de comercialização de títulos. Esse processo fez com que houvesse aumento da com-

5 Lei promulgada em 1933 nos EUA como consequência da crise de 1929. Criou a Federal Deposit Insurance Corporation, agência garantidora de créditos. O novo ato de 2009 removeu a separação que antes existia entre bancos comerciais e bancos de investimento.

6 CDS é conhecido como um contrato de derivativo de crédito, em que o comprador do swap faz pagamentos ao vendedor do mesmo até a data de vencimento do contrato. Em troca, o vendedor se compromete a pagar uma dívida de terceiros. O comprador de um CDS está especulando sobre a possibilidade de risco de contraparte do terceiro. 
petição dentro do setor e, assim, as instituições financeiras começaram a buscar a todo custo tirar vantagens de linhas de negócios mais lucrativas, muitas vezes com inovações financeiras que permitiam competir diretamente com as entidades que originalmente ocupavam os segmentos.

O fato é que durante o processo de liberalização financeira houve uma confiança exagerada por parte do mercado nos arcabouços regulatórios existentes e é nesse quadro de desregulamentação financeira e de baixa percepção de risco pelos agentes econômicos que se instaurou a crise norte-americana. A mesma teve como princípio a expansão do mercado subprime, composto por tomadores de empréstimo muitas vezes sem vínculo empregatício, sem fonte de renda confiável ou qualquer forma de garantia. Tais indivíduos ficaram conhecidos como NINJAS, abreviação para "No Income, No Job, No Assets", ou seja, sem renda, sem emprego e sem ativos.

O excesso de confiança do mercado e a consequente gradual deterioração das margens de segurança causou um boom desse segmento de atuação por parte das instituições, sendo necessária a criação de novas práticas e instrumentos financeiros a fim de se evitar a regulamentação e o controle dos supervisores. Configurou-se, desse modo, um ambiente de inovação extrema que acabou sufocando o sistema. Segundo Pereira (2011), a busca pelos agentes NINJAS foi um reflexo do crescimento da busca incessante pelo lucro sendo necessários produtos inovadores para alcançar esses novos clientes. O cenário era de exaustão da demanda da classe média e, dessa forma, o mercado subprime era a saída para rentabilizar novos negócios. Na época de tal processo, as taxas de juros nos EUA eram relativamente baixas e havia a ilusão de que esses empréstimos eram de baixo risco. O processo de inovação sufocante permitiu que em meados de 2006 mais da metade das hipotecas fossem do tipo subprime, o que gerou um grande boom imobiliário construído a partir da securitização.? Dessa forma, segundo Dymski (2008), o risco das hipotecas subprime encontrava-se disfarçado via securitização. Esse processo chegou a tal ponto que nem o vendedor nem o comprador tinham noção do risco em que estavam incorrendo.

Entretanto, a situação começou a mudar, o Federal Reserve (FED) começou a aumentar a taxa de juros norte-americana e algumas das hipotecas com taxas variáveis começaram a ser modificadas; o índice de inadimplência começou a aumentar. Consequentemente, os preços das casas começaram a cair, a redução das receitas geradas pelos juros afetou o retorno dos ativos hipotecários securitizados. Agências de risco começaram a rebaixar os ratings ${ }^{8}$ desses títulos devido à queda de confiabilidade dos mesmos e alguns investido-

\footnotetext{
7 Prática financeira que agrupa vários tipos de passivos financeiros e os converte em títulos padronizados negociáveis no mercado de capitais

8 Opinião sobre a capacidade de um país ou uma empresa saldar seus compromissos financeiros.
} 
res foram forçados a vendê-los na baixa do mercado. Nesse contexto, a crise de crédito se transformou numa grave crise de liquidez e, assim, algumas instituições financeiras foram forçadas a declarar falência quando o valor de seus ativos caiu abaixo de suas obrigações.

Como fruto do processo de globalização financeira, a crise norte-americana rapidamente se alastrou por todo o mundo, confirmando as expectativas de que o sistema financeiro internacional estava sujeito ao risco de contágio. De acordo com a análise feita em Claessens et al. (2010), a crise pode ser explicada através de três fases pontuais. A primeira foi referente à exposição que os bancos possuíam ao mercado norte-americano, afetando inicialmente apenas alguns mercados e, logo após, devido à interconexão financeira entre os países, alastrando-se pela Europa. A segunda fase caracterizou-se pelo transbordamento através do mercado de ativos, fato esse que ocorreu via redução da liquidez, congelamento do crédito e declínio do valor das ações. Diante desse cenário, as principais autoridades monetárias começaram a injetar liquidez nas economias. A terceira e última fase da crise deu-se a partir da quebra do Lehman Brothers, instaurou uma crise sistêmica global, em que começaram a eclodir inquietações quanto à solvência das instituições financeiras e houve um comportamento de manada em que os investidores começaram a vender seus ativos, quase colocando a economia mundial à beira do colapso.

Segundo Farhi (2010, p. 1), a crise financeira internacional explicitou "[...] as enormes deficiências dos mecanismos de supervisão e regulação baseados na conviç̧ão que os mercados são eficientes e que a governança corporativa e a gestão e monitoramento dos riscos bancários haviam evoluído a ponto de serem consideradas as mais apropriadas e eficientes para se evitar a ocorrência deste tipo de episódio". A autora afirma ainda que tanto as regras do Acordo de Basileia como as de âmbito nacional estavam focadas na higidez financeira das instituições bancárias de forma individualizada ignorando, dessa forma, a importância sistêmica da interação entre instituições bancárias e não bancárias.

O ponto central é que, com a eclosão da crise, começou a se questionar a arquitetura atual do sistema financeiro internacional, seus mecanismos de regulação e supervisão. Nesse contexto insere-se a análise dos Acordos de Basileia, que deveriam propiciar maior segurança e resiliência ao sistema financeiro; porém não foi o que ocorreu no desenrolar da crise. O sistema vigente, Basileia II, mostrou ser falho, sendo necessários ajustes no seu escopo. Assim, o BCBS iniciou uma série de estudos sobre as causas e impactos da crise, buscando identificar possíveis falhas do modelo de regulação até então vigente, pois, mesmo com todo o aparato regulatório, a higidez dos bancos se revelou inadequada devido à baixa qualidade do capital. 
Durante o transcorrer do tempo inúmeras crises surgiram, o que demonstra a ineficiência dos marcos regulatórios e da ação dos Bancos Centrais em administrar suas economias. As últimas décadas foram marcadas por diversas crises apesar dos esforços. O fato é que os Acordos de Basileia não têm conseguido alcançar seu objetivo de proporcionar maior solidez e segurança ao sistema financeiro como um todo. Nesse contexto, o Comitê, em 2010, divulgou os documentos que servem de base ao Acordo de Basileia III, que será analisado na seção 4 .

\section{Cronologia dos Acordos de Basileia}

Como já mencionado, a década de 1970 foi marcada por um processo de liberalização e desregulamentação financeira. A maior liberdade dos bancos em agir tanto nos mercados domésticos quanto nos externos fez com que os riscos das operações financeiras aumentassem exponencialmente, provocando crises bancárias sucessivas e levando algumas instituições financeiras, como o banco alemão Herstatt Bank, à falência. Como resposta a estas crises, em 1975 foi divulgado um primeiro Acordo de Basileia que estabeleceu novos princípios normativos, principalmente em relação à supervisão das atividades de bancos estrangeiros, que ficou definida como função da nação hospedeira e de origem dos bancos internacionais.

Entretanto, depois do colapso do Acordo de Bretton Woods e da relutância de muitos países em ajudar financeiramente bancos pouco controlados, especialmente os provenientes de paraísos fiscais, ficou claro que o Acordo de 1975 era insuficiente. Dessa forma, em 1983 o Comitê de Basileia decidiu revisar o Acordo anterior, revisão esta considerada insatisfatória, pois não obteve êxito em uniformizar as diversas normas nacionais, principalmente as de cunho contábil, de forma a facilitar a supervisão das entidades reguladas.

O que se viu foi que o sistema financeiro internacional tornou-se cada vez mais vulnerável ao risco sistêmico, pois os marcos regulatórios vigentes à época estavam cada vez mais opacos e ineficientes. Esse cenário resultou na necessidade de uma regulação mais incisiva, que reduzisse o risco moral e transferisse aos bancos a obrigatoriedade de seguir certos padrões comportamentais com a administração de seus capitais. Assim, em 1988, surgiu o primeiro Acordo de Basileia que implantou esse tipo de exigência. Nele foi estabelecido que os bancos deveriam garantir seus compromissos com capital próprio de forma a garantir a solidez do sistema.

\subsection{Basileia I}

O Acordo promulgado em 1988, chamado de Basileia I, criou uma nova forma de regulação bancária. A responsabilidade da solidez do sistema bancário não 
se restringia agora apenas à figura do órgão regulador, sendo função também das instituições bancárias. Seus principais objetivos eram fortalecer e garantir a solidez do sistema bancário internacional e equalizar as competições bancárias a nível internacional. Dessa forma, buscava alinhar os custos regulatórios incorridos por bancos internacionalmente ativos sediados em diferentes países e também que possuíssem uma regulação satisfatória. Na realidade, o objetivo subjacente de Basileia I era beneficiar os bancos norte-americanos, pois os bancos europeus e japoneses estavam sujeitos a uma regulação menos rígida. Assim, as imposições de capital impostas aos bancos norte-americanos aplicar-se-iam também aos demais.

Basileia I basicamente abrangia apenas um risco em sua metodologia, o de crédito. Dessa forma, deixava de lado os outros riscos aos quais as instituições bancárias estão expostas, como o risco de liquidez (associado a cada classe de ativo), o risco de mercado (associado à volatilidade das taxas das aplicações financeiras às quais os bancos estão expostos), o risco operacional (relativo à possibilidade de ocorrência de perdas resultantes de falha, deficiência ou inadequação de processos internos, pessoas e sistemas, ou de eventos externos) e o risco cambial (decorrente da variação cambial das aplicações em que a instituição está exposta), este último extremamente importante no mundo globalizado em que o mercado opera com taxas cambiais flutuantes.

Ciente dessas limitações, a partir de 1995, o Comitê começou a aceitar o uso de modelos internos utilizados pelos bancos para mensurar seu próprio capital ponderado pelo risco. Com essa decisão, as autoridades admitiram ser mais eficaz que houvesse o monitoramento dos cálculos e métodos de mensuração de risco do que apenas gerir suas exposições. Segundo Carvalho (2005), a liberação do uso de modelos internos sinalizou o reconhecimento por parte dos organismos supervisores de suas próprias limitações em antecipar os comportamentos imprudentes dos bancos, num contexto de aumento de complexidade das operações bancárias e de elevada propagação de inovações financeiras.

No ano de 1996 houve a edição de uma emenda que incorporou ao Acordo o requerimento de capital relativo ao risco de mercado. Esta demonstrou possuir um caráter inovador, pois adicionou mecanismos mais avançados de cálculo das exposições voltados para o incentivo de desenvolvimento de ferramentas de gerenciamento de risco do próprio mercado bancário como base para o cálculo dos requerimentos de capital. Como já explanado, Basileia I fez com que as instituições financeiras devessem manter capital proporcional não só ao volume de seu ativo, mas também à exposição aos riscos. Inicialmente a ideia do Acordo era que ele deveria abranger apenas os bancos internacionalmente ativos no âmbito do G10, ${ }^{9}$ porém o que se viu é que o mesmo foi adotado em mais de 100 sistemas bancários

9 Organização internacional composta por onze economias desenvolvidas. São elas: Bélgica, Canadá, Estados Unidos, França, Itália, Japão, Holanda, Reino Unido, Alemanha, Suécia e Suíça. 
o que fez com que, de certa forma, houvesse uma harmonização regulatória no âmbito do sistema bancário mundial.

Apesar de tal avanço regulatório, a solidez do sistema ainda não se encontrava num patamar satisfatório com as mudanças citadas. Basileia I não se mostrou eficiente em evitar novas crises, sendo alvo de críticas devido ao fato de ser simples demais. Sua metodologia limitada acabou por gerar diversas operações de arbitragem, em especial, o descolamento do capital regulatório do econômico, com a implantação por parte dos bancos de modelos internos de gerenciamento dos riscos. Além disso, o Acordo não abordou de maneira satisfatória o gerenciamento de instrumentos financeiros securitizados e derivativos frutos do constante processo de inovação financeira já presente à época. Dessa forma, tornou-se necessária uma reformulação ampla do Acordo, surgindo então Basileia II.

\subsection{Basileia II}

No ano de 2004 foi publicado o Acordo de Basileia II, que tentou superar as falhas do Acordo anterior com uma estrutura regulatória inovadora e mais complexa. Antes de ele ser implementado vários estudos de impacto foram efetuados pelo Comitê a fim de mensurar, com certo grau de confiança, os efeitos de sua aplicação.

A estrutura de Basileia II é dividida em três pilares, em que cada um tem efeito complementar e harmônico ao outro. Nesse Acordo houve a concepção de que os requerimentos de capital deveriam ser mais sensiveis aos riscos incorridos e sua aplicação se estendeu aos bancos internacionalmente ativos, incluindo as holdings ${ }^{10}$ bancárias ou controladoras. Seus pilares são designados por:

Pilar I - Cálculo dos Requerimentos de Capital: consiste basicamente na exigência de capital a que as instituições bancárias estão sujeitas de acordo com três tipos de risco: de crédito, de mercado e operacional. Assim, o novo acordo institui a cobrança de capital relativa ao risco operacional que não estava presente no Acordo anterior.

Pilar II - Processos de Supervisão: relaciona-se à atividade de supervisão pelos órgãos responsáveis. A ideia deste é complementar os requerimentos de capital previstos no primeiro pilar, assegurando que as instituições bancárias realizem as melhores práticas e, dessa forma, possuam sempre o nível de capital adequado para garantir sua solidez e solvência. O pilar também incentiva o aprimoramento de técnicas de gerenciamento e monitoramento dos riscos.

10 Forma de sociedade criada com o objetivo de administrar um conglomerado (grupo de empresas). A holding administra e possui a maior parte das ações ou cotas das empresas pertencentes ao grupo. 
Pilar III - Disciplina de Mercado: refere-se às melhores práticas por parte das instituições bancárias no que tange à divulgação das informações, isto é, uma boa política de disclosure ${ }^{11}$ e disciplina do mercado. Dessa forma, dirime as incertezas presentes no mercado e aumenta o nível de confiança dos consumidores e clientes, aumentando o nível de utilização dos instrumentos bancários. Este pilar elenca uma série de informações quantitativas e qualitativas que devem ser disponibilizadas ao mercado e ao público em geral em periodicidade definida.

Basileia II possui uma abordagem "micro", voltada para a figura do banco de forma individualizada, dispondo que as próprias instituições bancárias deveriam disciplinar sua exposição aos riscos sendo estimuladas a tomar tal atitude devido à fiscalização dos órgãos reguladores. Dessa forma, estando os bancos solventes de forma individualizada, a premissa era de que o sistema estaria sólido como um todo.

Entretanto, o BCBS falhou ao não abordar diversos pontos como os efeitos da globalização e da liberalização financeira e a consequente correlação do sistema bancário com outros sistemas com aparatos regulatórios inadequados ou até mesmo inexistentes. O Comitê falhou, em particular, ao não analisar a dinâmica dos ciclos econômicos que conduzem, por meio de processos cumulativos, à redução de percepção dos riscos e consequente redução das margens de segurança e maior vulnerabilidade das unidades econômicas.

A partir uma análise "minskyana", pode-se destacar a existência de uma propensão das instituições financeiras a diminuírem sua percepção ao risco (quanto ao risco do tomador de crédito) em períodos de prosperidade econômica, e passam a adotar uma postura mais acomodatícia na concessão de novos empréstimos. ${ }^{12}$ Desse modo, os bancos tendem a aumentar sua alavancagem em períodos prósperos e, inversamente, em períodos de desaceleração econômica a tendência é que os bancos diminuam repentinamente seus empréstimos, acarretando uma retração geral do nível de crédito e o aumento das exigências de capital a fim de evitar possíveis quebras.

Tal comportamento faz com que justamente nos períodos em que deveria haver maior liberação de crédito na economia visando estimular as atividades no

11 Divulgação pelas companhias de toda informação, positiva ou negativa, que poderia subsidiar uma decisão de investimento.

12 Segundo Paula e Alves Júnior (2003, p. 154), no ciclo econômico segundo Minsky, o "efeito retroalimentador entre investimentos e empréstimos bancários [no boom cíclico] contribuiria para validar as estruturas financeiras das firmas, com impactos positivos sobre o estado de expectativas quanto aos seus negócios. Neste contexto de crescimento, os bancos que mais obtêm lucros são aqueles que mais emprestam. A maior alavancagem e a menor liquidez dos ativos, antes temida pelos banqueiros por aumentar a exposição dos bancos, passa a compor a estratégia dos bancos ante o imperativo da concorrência bancária: deve-se fazer o que os demais bancos, que estão obtendo lucros significativos, estão fazendo, sob pena de redução nas taxas de crescimento e do market-share. No decorrer deste processo, o banqueiro não percebe a ocorrência de qualquer aumento na sua exposição ao risco de crédito". 
país, a oferta de crédito se retrai. Isso faz com que haja um agravamento da recessão e consequente eclosão de diversos outros fatores nocivos à economia como um todo, o nível de confiança dos consumidores cai, o nível de consumo arrefece e diversos setores da economia são prejudicados.

Essa análise exemplifica de forma breve um dos principais motivos de Basileia II não ser adequado como marco regulatório do sistema bancário. Este acordo demonstrou ser pró-cíclico, ou seja, acentuou os ciclos econômicos em suas extremidades, quando na verdade os ciclos deveriam ser estabilizados. Em outras palavras, Basileia II acentuou os efeitos da crise devido à sua correlação positiva com os ciclos econômicos, quando deveria fazer o contrário.

Diversas características presentes em Basileia II contribuíram para acentuar a pró-ciclicidade do crédito bancário. Segundo Freitas (2011), pode-se citar a própria métrica do cálculo das exigências de capital ao utilizar a própria avaliação de riscos do setor bancário. Por exemplo, o risco ao que os bancos possuem maior exposição é o risco de crédito, sendo seu cálculo baseado em variáveis cujo comportamento é, em sua essência, pró-cíclico. A partir do momento que as premissas do cálculo deste risco têm por base os ratings das agências, que são ligados fortemente ao modo como evoluem as expectativas dos agentes, a tendência é que os requerimentos de capital sejam maiores em períodos de stress.

\section{O Novo Acordo de Basileia III - Análise do Modelo}

A crise norte-americana revelou todas as deficiências e falhas de Basileia II e também os efeitos nefastos do processo de desregulamentação e liberalização financeira na economia mundial. Como resposta à crise, o BCBS divulgou seu novo Acordo, Basileia III, que não constituiu um grande avanço em termos de inovação e podendo ser considerado mais uma evolução, um aprimoramento de Basileia II.

Entre os pontos positivos presentes no novo Acordo, pode-se citar que houve a compreensão por parte do regulador de que a regulação financeira não pode, sob nenhuma hipótese, ter base no indivíduo e sim na economia como um todo (LEITE; REIS, 2011). Houve também a percepção de que a crise não se iniciou no sistema bancário, entretanto o mesmo serviu como meio de propagação. Foram identificados diversos fatores indicativos da fragilidade bancária, como a alavancagem excessiva, a baixa qualidade do capital e a baixa margem de liquidez das instituições.

Assim, em abril de 2009, houve a criação do Comitê de Estabilidade Financeira (FSB), ${ }^{13}$ objetivando o fortalecimento dos mecanismos de regulação e super-

13 O FSB foi criado para coordenar a nível internacional o trabalho das autoridades financeiras nacionais e de instituições internacionais para desenvolver e implementar políticas regulatórias, de supervisões e outras políticas financeiras, sendo coordenado pelo Presidente do Banco da 
visão financeira. Sob a tutela do BCBS ficou a responsabilidade do estabelecimento de um cronograma das reformas e houve o aumento de sua representatividade, sendo incluídos em seu corpo de países, como Brasil, China, Rússia, entre outros. Em 2010 o Bank for International Settlements, seguindo as recomendações do G20, divulgou os dois documentos que servem de base ao novo marco regulatório: "Basel III: A global regulatory framework for more resilient bank and banking system" (2010) e "Basel III: International framework for liquidity risk measurement, standards and monitoring" (2010).

Analisando os títulos dos documentos pode-se notar, de certa forma, qual o novo enfoque que o Comitê irá adotar em seu novo marco regulatório. Há novamente a inclusão do conceito de liquidez como ponto de fundamental preocupação e nota-se a mudança de postura quando se trata não apenas da resiliência dos bancos de forma individual, mas também da resiliência do sistema bancário como um todo.

Segundo Sobreira e Silva (2012), o Acordo de Basileia III buscou ampliar as disposições contidas no segundo Acordo, de 2004. Dessa forma, foi mantido o foco da estratégia regulatória sobre a solvência dos bancos. Já Reis (2011) afirma que as mudanças propostas são na realidade o reconhecimento por parte do Comitê do fracasso do modelo de regulação até então vigente. Este autor ressalta que o foco deste novo Acordo será reforçar os requisitos de capital próprio das instituições, aumentar consideravelmente a qualidade desses fundos próprios e reduzir o risco sistêmico. Além disso, Basileia III inclui em seu escopo instrumentos que visam reduzir a pró-ciclicidade presente nos marcos regulatórios anteriores, dentre estes destaca-se o buffer de capital que será analisado a seguir.

\subsection{O Buffer de Capital Contracíclico}

A ideia do buffer contracíclico é que seu valor dependa do momento do ciclo econômico vivenciado pelo país, de forma a constituir reservas de capital em tempos de bonança para utilizá-las em períodos de crise. O Comitê definiu no documento "Guidance for National Authorities Operating the Countercyclical Capital Buffer" (2010) que o buffer contracíclico deve variar de 0 (zero) a 2,5\% dos ativos ponderados pelo risco, dependendo do ponto do ciclo da economia, medido através da relação Crédito ${ }^{14} / \mathrm{PIB}^{15}$ anual.

A metodologia do buffer $\left(b_{t}\right)$ num momento $t$ pode ser resumida da seguinte forma: seja $x_{t}$ a razão crédito/PIB no instante $t$, e seja $\overline{x_{t}}$ sua tendência suavizada de

\footnotetext{
Inglaterra, Mark Carney, e seu secretariado estabelecido no BIS, na cidade de Basileia.

14

Todas as fontes de fundos de dívida para o setor privado.

15 Soma (em valores monetários) de todos os bens e serviços produzidos num país, inclusive os pagamentos a fatores de produção no exterior, em determinado período (geralmente um ano), e sem desconto dos gastos de depreciação.
} 
longo prazo. ${ }^{16} \mathrm{O}$ ponto de referência proposto $\left(z_{t}\right)$ neste momento seria o desvio (gap) de $x_{t}$ em relação à $\overline{x_{t}}$, isto é: $z_{t}=x_{t}-\overline{x_{t}}$. Dessa forma, o valor do buffer se dá de acordo com a seguinte fórmula:

$$
b_{t}=\left\{\begin{array}{lc}
0 & \text { se } z_{t}<L \\
\frac{z_{t}-L}{H-L} \times 2,5 \% & \text { se } L<z_{t}<H \\
2,5 \% & \text { se } z_{t}>H
\end{array}\right.
$$

Onde L e H são, respectivamente, os limites inferior e superior do gap definidos em Basileia III como $\mathrm{L}=2 \%$ e $\mathrm{H}=10 \%$. Assim, $b_{t}$ será zero (não há acumulação de reservas) quando o desvio estiver abaixo do limite inferior e estará no seu nível máximo (2,5\% dos ativos ponderados pelo risco) quando estiver acima do limite superior. Entre os dois níveis, $b_{t}$ é uma função linear crescente do desvio.

O Gráfico 1 exemplifica o modelo: nos pontos em que a razão Crédito/PIB está acima da tendência, o gap é positivo e, logo, se o desvio for maior que $2 \%$, capital deve ser armazenado a fim de se proteger o sistema bancário de períodos de crescimento excessivo do crédito. Dessa forma, de acordo com a magnitude do gap, as instituições deverão guardar mais ou menos capital.

Gráfico 1- Relação crédito/PIB e sua tendência

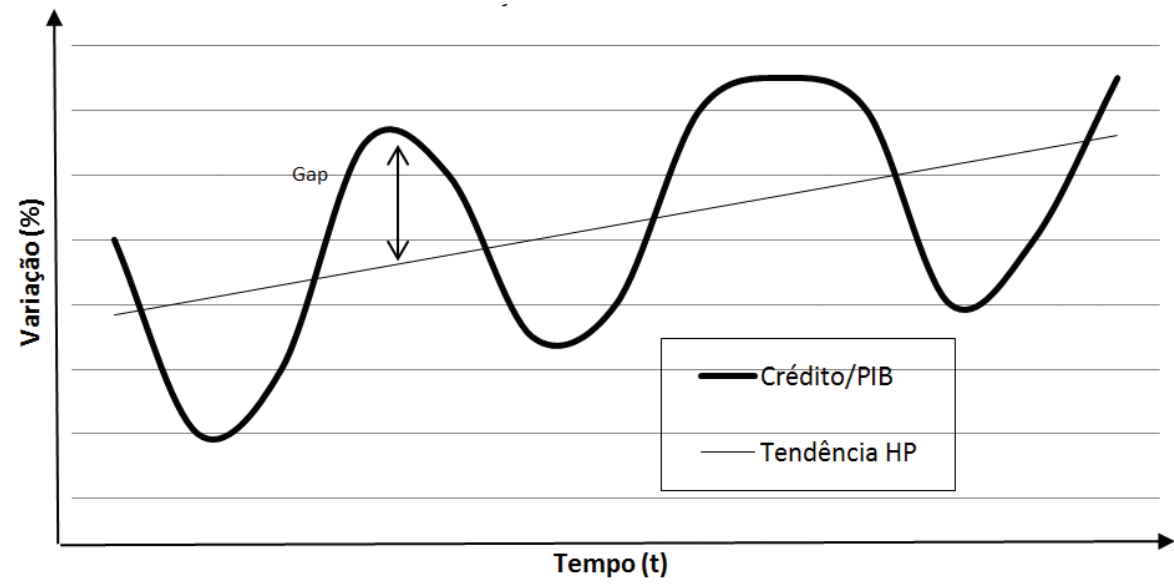

Fonte: Elaboração própria.

Entretanto, desde a divulgação do documento, o BCBS se mostrou receoso quanto à eficiência do uso do gap como ponto de referência para a tomada de

16 Neste caso é utilizado o filtro Hodrick-Prescott, técnica muito usada em ciclos reais de negócios, para extrair a tendência de séries como a do PIB por exemplo. Sendo utilizado um parâmetro de suavização $\lambda=400.000$ 
decisões do buffer. Sugeriu, inclusive, que as autoridades procurassem alternativas de cálculo. Tal receio acabou se mostrando oportuno visto que não foi levado em consideração como a variável do gap do Crédito/PIB se correlaciona com indicadores padrão do ciclo de negócios como, por exemplo, a taxa de crescimento do PIB, o que demonstrou ser uma limitação considerável do modelo.

Como exemplo, foi destacada na análise feita por Repullo e Saurina (2011) para o Reino Unido durante o período 1986-2009 a relação entre o gap do Crédito/ PIB e a taxa de crescimento do PIB. Conforme o Gráfico 2, existe uma clara correlação negativa entre as variáveis: quando o crescimento é baixo (característica presente em recessões), o gap Crédito/PIB tende a ser alto, e vice-versa.

Gráfico 2 - Gap crédito/PIB e crescimento do PIB, Reino Unido, 1986-2009

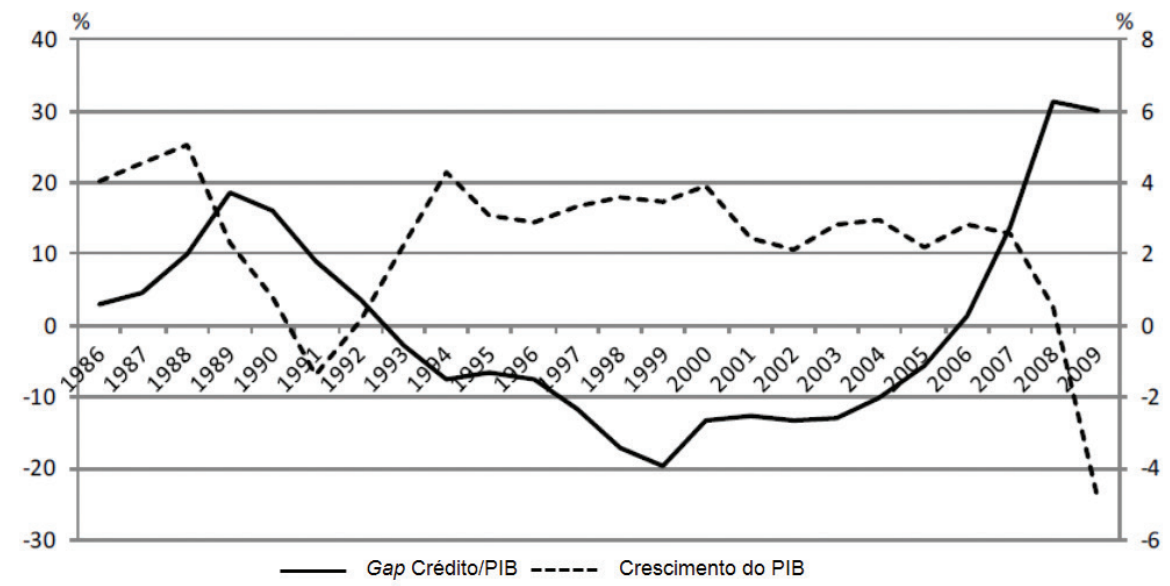

Fonte: Repullo e Saurina (2011, p. 10).

Tal comportamento também foi notado pelos autores em grandes economias - como a da França, Japão, Alemanha, Itália e Espanha - com exceção dos Estados Unidos. A Tabela 1 mostra a correlação entre o crescimento do PIB (PIB) e o gap crédito/PIB (Gap ) e também a correlação entre o crescimento do PIB e o buffer contracíclico (B) para diversos países, no período 1986-2009. 
Tabela 1 - Análise de buffer contracíclico (1986-2009)

\begin{tabular}{ccc}
\hline País & Correlação $\left(\mathbf{P I B}_{\mathbf{t}}, \mathbf{G} \mathbf{a p}_{\mathbf{t}}\right)$ & Correlação $\left(\mathbf{P I B}_{\mathbf{t}}, \mathbf{B}_{\mathbf{t}}\right)$ \\
\hline França & $-0,31$ & $-0,34$ \\
Alemanha & $-0,26$ & $-0,14$ \\
Itália & $-0,03$ & $-0,07$ \\
Japão & $-0,32$ & $-0,38$ \\
Espanha & $-0,03$ & 0,27 \\
Reino Unido & $-0,58$ & $-0,48$ \\
Estados Unidos & 0,31 & 0,23 \\
\hline
\end{tabular}

Fonte: Repullo e Saurina (2011, p. 12).

A conclusão que se pode tirar de tal avaliação é que a variável gap escolhida como referência para a tomada de decisões do buffer contracíclico aparenta ser falha. Sua correlação com o crescimento do PIB é geralmente negativa, o que significa que o gap tende a sinalizar a redução da cobrança de capital quando o crescimento do PIB é alto e aumentar o requerimento quando o crescimento é baixo. Dessa forma, o buffer proposto por Basileia III parece contradizer o que o G-20 solicitou aos bancos: construir buffers de recursos em tempos de prosperidade para serem utilizados quando as condições econômicas piorassem.

\subsection{Alternativa de Cálculo}

Assim sendo, com o objetivo de obter maior segurança e reduzir as distorções do modelo, alternativas devem ser propostas. Ainda segundo o artigo de Repullo e Saurina (2011), uma delas pode ser utilizar o desvio do crescimento do crédito, e não da relação crédito/PIB, em relação a sua média de longo prazo como referência para a tomada de decisões do buffer. Tal variável seguiria o mesmo pensamento do gap em termos de funcionar como indicador antecedente de uma crise do sistema bancário. Efetuando abordagem similar à efetuada anteriormente, pode-se ver no Gráfico 3 que a taxa de crescimento do crédito doméstico para o setor privado do Reino Unido e a correspondente evolução do crescimento do PIB são positivamente correlacionadas, o que sugere que tal variável seja mais adequada que a proposta pelo BCBS. Como a análise é feita para apenas um país, caberia um aprofundamento analítico maior para tal alternativa de cálculo do buffer. 
Gráfico 3 - Crescimento do crédito e crescimento do PIB, Reino Unido (1986-2009)

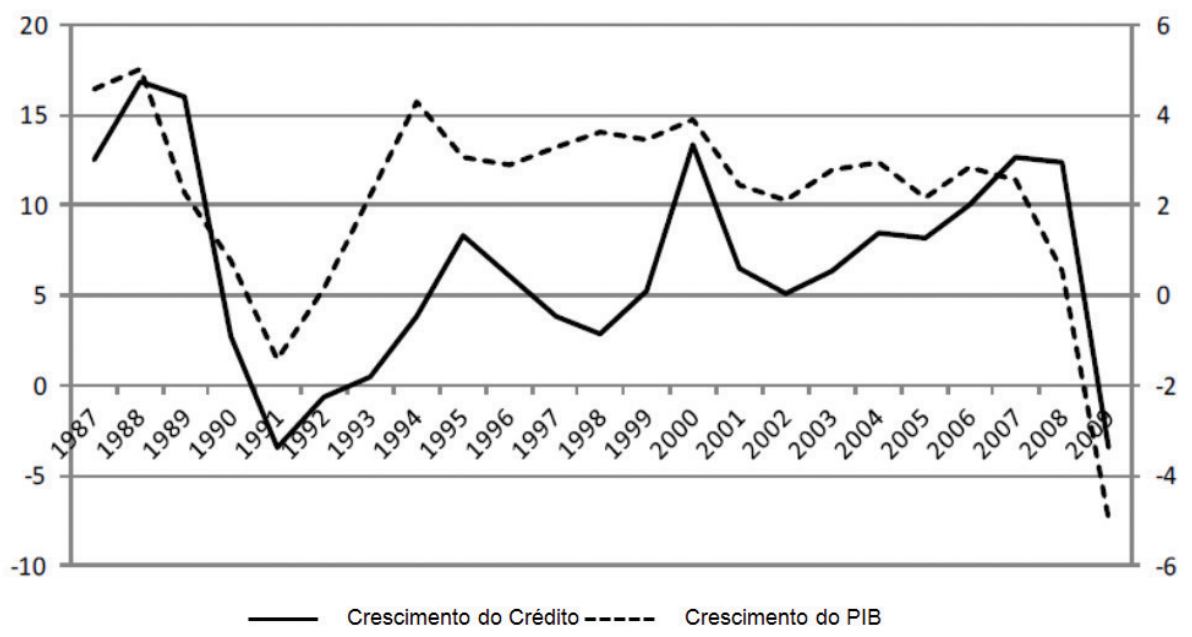

Fonte: Repullo e Saurina (2011, p. 16).

\section{Análise da Eficiência do Buffer Contracíclico no Setor Bancário Brasileiro}

Basileia III está em fase de implantação no sistema bancário brasileiro. Conforme explicitado anteriormente, existem diversas dúvidas acerca da efetividade do novo Acordo, principalmente no tocante ao buffer contracíclico, que é objeto de pesquisa do presente trabalho. Assim, torna-se necessária a avaliação do comportamento deste Acordo no cenário nacional utilizando-se a metodologia sugerida pelo BCBS. Antes, porém, analisa-se a adoção de Basileia III no Brasil.

\subsection{Implantação de Basileia Ill no Setor Bancário Brasileiro}

Segundo relatório do Banco Central do Brasil (BCB), o Sistema Bancário Brasileiro encontra-se em boa posição quando comparado a outros países do G20 (BANCO CENTRAL DO BRASIL, 2013). O fato de o país ter uma regulação conservadora aliada à supervisão forte e orientada ao risco faz com que o Sistema Financeiro Internacional (SFN) não apresente as principais características que levaram à eclosão da crise internacional.

O BCB divulgou no dia $1^{\circ}$ de março de 2013 diversos normativos que deram início à efetiva implantação do novo modelo regulatório no mercado bancário brasileiro. No tocante aos novos cálculos de requerimento de capital é interessante ressaltar que o BCB, desde Basileia I, adotava um fator de ponderação aplicado aos ativos de risco no valor de $11 \%$, sendo que o padrão mundial sugeria $8 \%$ para este fator. Isto é, o índice mínimo exigido pelo BCB às instituições financeiras na- 
cionais sempre foi mais elevado que no exterior o que, de certa forma, garantiu a solidez do sistema bancário nacional ao longo do período mais severo da crise financeira internacional.

Adotando Basileia III, o mercado nacional finalmente alinhar-se-á ao internacional, exigindo dos bancos a manutenção de um índice mínimo de Basileia variando de $10,5 \%$ a $13 \%$ dos ativos ponderados pelo risco. Dessa forma, o BCB determinou que haverá uma convergência paulatina do requerimento mínimo de capital, saindo dos $11 \%$ cobrados atualmente e chegando aos $8 \%$ sugeridos em Basileia III. Assim como também haverá a introdução gradual das cobranças de capital do buffer de conservação de capital e do buffer contracíclico. Tal adequação encontra-se prevista na Tabela 2, a partir de informações do BCB.

Tabela 2 - Implementação de Basileia III no Brasil

\begin{tabular}{|c|c|c|c|c|c|c|c|}
\hline & \multicolumn{7}{|c|}{ Requerimento de Capital - Evolução Anual } \\
\hline $\begin{array}{c}\text { mento de } \\
\text { Capital }\end{array}$ & $2013^{*}$ & 2014 & 2015 & 2016 & 2017 & 2018 & 2019 \\
\hline $\begin{array}{l}\text { Capital Prin- } \\
\text { cipal (CP) }\end{array}$ & $4,50 \%$ & $4,50 \%$ & $4,50 \%$ & $4,50 \%$ & $4,50 \%$ & $4,50 \%$ & $4,50 \%$ \\
\hline $\begin{array}{c}\text { Capital Ní- } \\
\text { vel } 1\end{array}$ & $5,50 \%$ & $5,50 \%$ & $6,00 \%$ & $6,00 \%$ & $6,00 \%$ & $6,00 \%$ & $6,00 \%$ \\
\hline $\begin{array}{l}\text { Capital Míni- } \\
\text { mo (CM) }\end{array}$ & $11,00 \%$ & $11,00 \%$ & $11,00 \%$ & $9,875 \%$ & $9,25 \%$ & $8,625 \%$ & $8,00 \%$ \\
\hline $\begin{array}{l}\text { Adicional de } \\
\text { Capital Prin- } \\
\text { cipal (ACP) }\end{array}$ & - & - & - & $\begin{array}{l}{[0,625 \%} \\
\text { a } 1,25 \%]\end{array}$ & $\begin{array}{l}{[1,25 \%} \\
\text { a } 2,5 \%]\end{array}$ & $\begin{array}{l}{[1,875 \%} \\
\text { a 3,75\%] }\end{array}$ & $\begin{array}{c}{[2,50 \% \mathrm{a}} \\
5,00 \%]\end{array}$ \\
\hline $\mathrm{CP}+\mathrm{ACP}$ & $4,50 \%$ & $4,50 \%$ & $4,50 \%$ & $\begin{array}{l}{[5,125 \%} \\
\text { a } 5,75 \%]\end{array}$ & $\begin{array}{c}{[5,75 \%} \\
\mathrm{a} \\
7,00 \%]\end{array}$ & $\begin{array}{l}{[6,375 \%} \\
\text { a } 8,25 \%]\end{array}$ & $\begin{array}{c}{[7,00 \% \text { a }} \\
9,50 \%]\end{array}$ \\
\hline $\mathrm{CM}+\mathrm{ACP}$ & - & $11,00 \%$ & $11,00 \%$ & $\begin{array}{c}{[10,50 \%} \\
a \\
11,125 \%]\end{array}$ & $\begin{array}{c}{[10,50 \%} \\
a \\
11,75 \%]\end{array}$ & $\begin{array}{c}{[10,50 \% \text { a }} \\
12,375 \%]\end{array}$ & $\begin{array}{c}{[10,50 \% \mathrm{a}} \\
13,00 \%]\end{array}$ \\
\hline
\end{tabular}

Fonte: Elaboração própria a partir de Resolução ${ }^{\circ}$ 4.193/13 (BANCO CENTRAL DO BRASIL, 2015a).

Nota: Datas referentes a 01/jan. *01/10/2013.

A adoção integral de Basileia III no mercado brasileiro está inicialmente prevista para janeiro de 2019. Vale ressaltar que o BCB irá adotar o acordo integralmente. Para melhor ilustrar a estrutura do modelo regulatório a ser adotado no Brasil, a Figura 1 sintetiza a arquitetura do Acordo. 
Figura 1 - Estrutura básica de Basileia III no Brasil

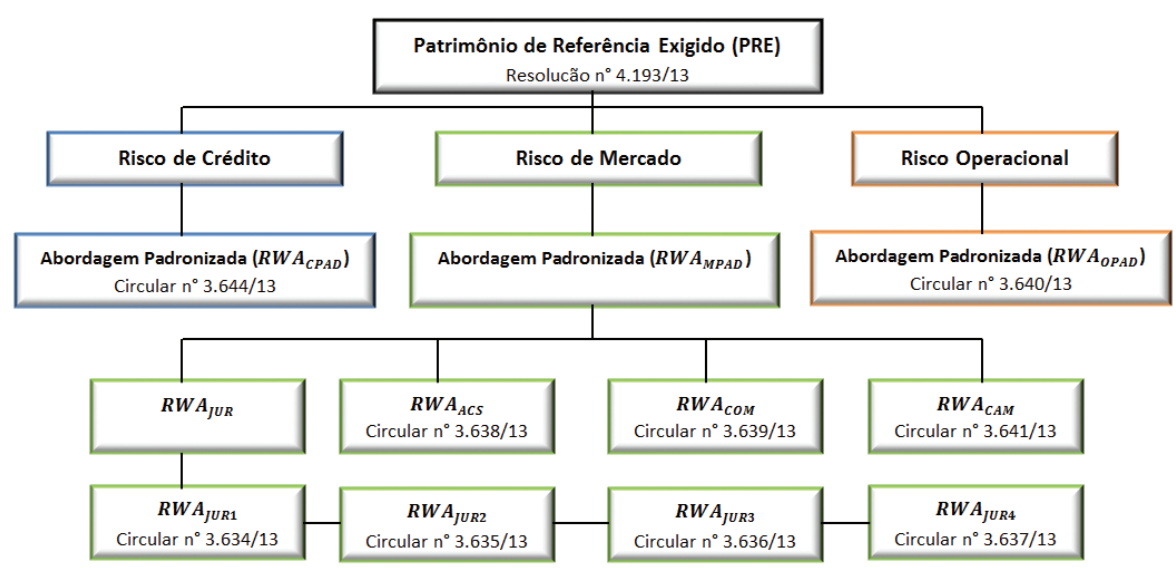

Fonte: Associação Brasileira das Entidades dos Mercados Financeiro e de Capitais (2013).

O patrimônio de referência exigido (PRE) corresponde ao capital necessário que a instituição deve manter para fazer face aos riscos de mercado, de crédito e operacional, dessa forma:

$$
P R E=R W A_{C P A D}+R W A_{M P A D}+R W A_{O P A D}
$$

Onde:

$R W A_{C P A D}$ representa o requerimento de capital relativo ao risco de crédito; $R W A_{M P A D}$ representa o requerimento de capital relativo ao risco de mercado; $\mathrm{e}$ $R W A_{O P A D}$ representa o requerimento de capital relativo ao risco operacional.

Pode-se ver na estrutura básica do Acordo que o módulo de risco de mercado se divide em quatro submódulos: risco de ações $\left(R W A_{A C S}\right)$, risco de commodities $\left(R W A_{\text {COM }}\right)$, risco cambial $\left(R W A_{C A M}\right)$ e risco de taxa de juros $\left(R W A_{J U R}\right)$. Este último se divide ainda em quatro parcelas: $R W A_{J U R 1}, R W A_{J U R 2}, R W A_{J U R 3}$ e $R W A_{J U R 4}$.

Devido ao fato de o sistema bancário brasileiro possuir uma boa reserva de capital, os bancos nacionais precisarão de um esforço muito menor para se adequar às novas regras do que os bancos estrangeiros. De acordo com simulações feitas pelo $\mathrm{BCB}$, não haverá nenhuma necessidade de capital principal adicional para o Sistema Financeiro Nacional (SFN) durante o período de transição (2013 - 2019).

No tocante ao impacto na oferta de crédito, o Banco Central do Brasil (2013, p.7) afirma que o Basileia III não a impactará de forma significativa. De acordo 
com o Banco, as razões para a neutralidade da implantação do Novo Acordo sobre a oferta de crédito se dá pelas seguintes razões: (i) o SFN é sólido e está bem capitalizado; (ii) os prazos de implantação do Acordo são longos, estendendo-se até 2022; (iii) a publicação de Basileia III reduz incertezas regulatórias, aumenta a clareza e a possibilita o melhor planejamento por parte das instituições financeiras, fato este que gera maior segurança no sistema e (iv) a sinalização por parte dos bancos de estarem preparados para a implantação de Basileia III e reconhecerem a importância do diferencial prudencial-regulatório nacional para seus negócios.

\subsection{Comportamento da Variável Crédito/PIB no Brasil}

Para efetuar uma análise da adoção do buffer contracíclico no setor bancário brasileiro, foram obtidas, do sistema de séries temporais do $\mathrm{BCB}$, as séries trimestrais do nível agregado de crédito ao setor privado, e, do site do Ipeadata (2015), o PIB trimestral nominal brasileiro. Tais séries abrangem o período que vai desde o primeiro trimestre de 1990 até o último de 2012, totalizando 92 observações. ${ }^{17}$

A partir desses dados calculou-se a razão crédito/PIB, sua tendência de longo prazo e os gaps de cada período. Feito isto, comparou-se o comportamento da série dos gaps com a variação do PIB. O Gráfico 4 ilustra o comportamento do crédito/PIB ao longo do tempo e sua tendência de longo prazo (filtro HP).

Gráfico 4 - Série crédito/PIB e sua tendência de longo prazo (1T/90 - 4T/12)

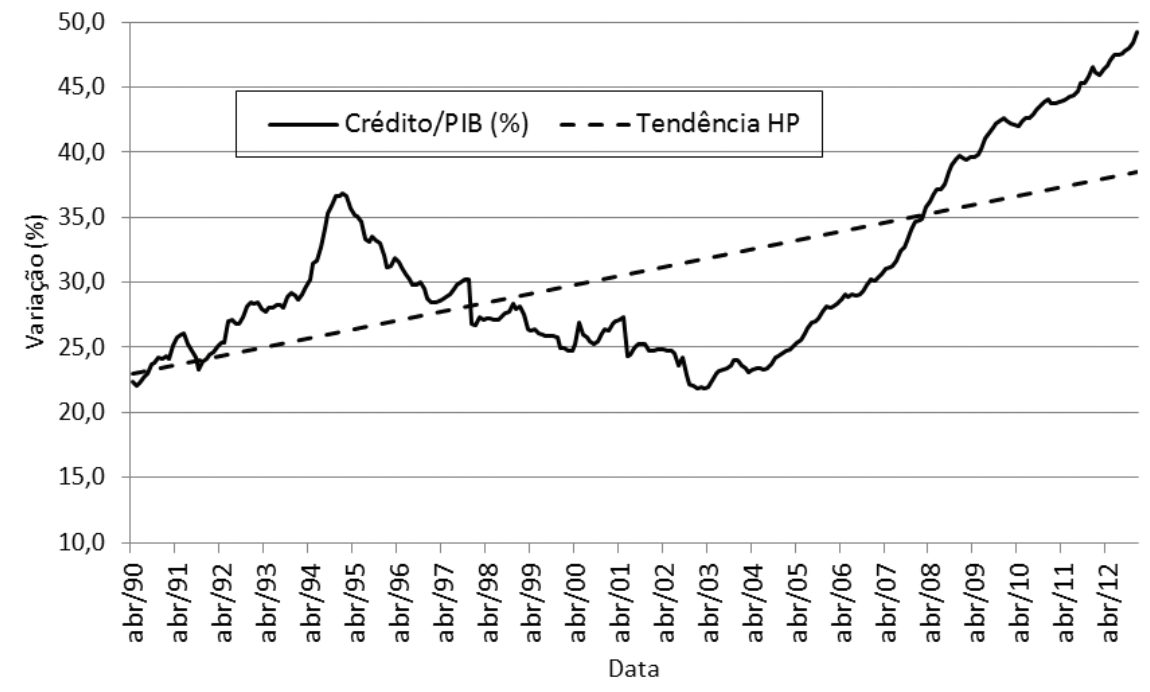

Fonte: Elaboração própria com base em dados do Banco Central do Brasil (2015b).

17 A escolha do período decorre das várias mudanças na metodologia na série de crédito do BCB. 
Analisando o Gráfico 4 é possível notar que de 2004 até 2010 existe uma tendência de alta da razão crédito/PIB, verificando-se também a presença de desvios de pequena magnitude no período citado. O Gráfico 5 ilustra exatamente o comportamento desses desvios (gap) e compara sua série com a da variação do PIB.

Gráfico 5 - Série histórica Gap crédito/PIB x variação do PIB (1T/90 - 4T/12)

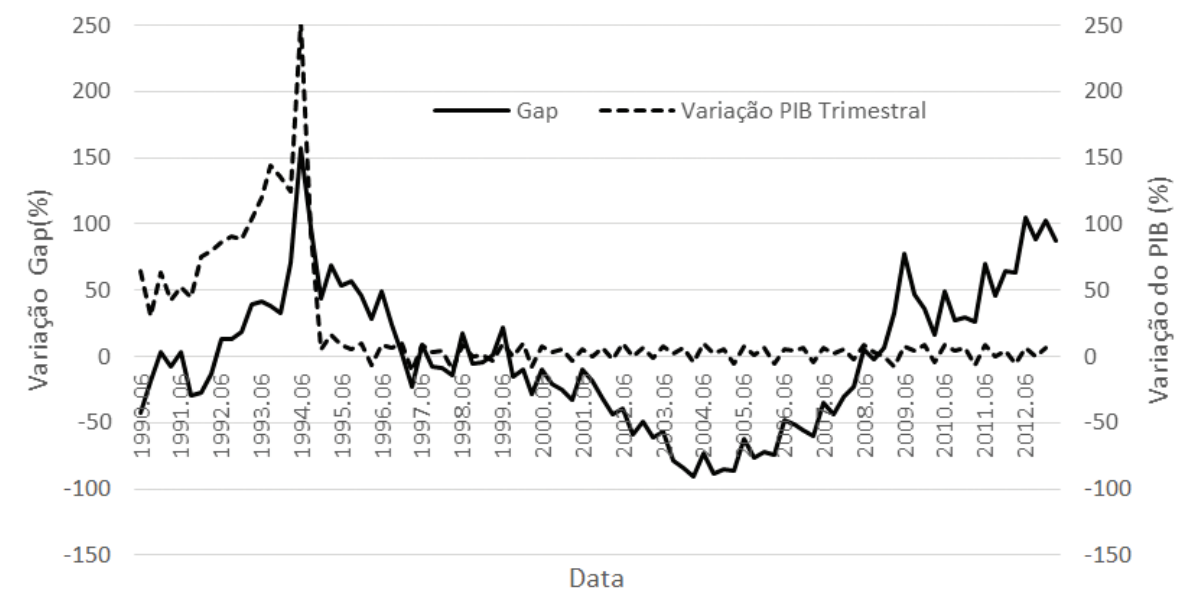

Fonte: Elaboração dos autores com base em dados do Banco Central do Brasil (2015b) e Ipeadata (2015).

O gráfico demonstra haver correlação positiva no início da série, entretanto nos anos relativos à crise do subprime esse comportamento não se aplica. Enquanto o Gap apresenta maior variabilidade, a variação do PIB mantém-se praticamente estável. Ou seja, há indícios de que, em períodos recessivos, o valor do Gap e a variação do PIB possuem correlação negativa. Tal característica contradiz o principal objetivo do buffer contracíclico que é criar reservas de capital em tempos de expansão (variação positiva do PIB) para serem utilizadas em períodos recessivos (variação negativa do PIB). Para corroborar a análise gráfica, calcularam-se os coeficientes de correlação entre as duas variáveis para três períodos diferentes: (i) série completa (1T/90 - 4T/12); (ii) anos de 2008 e 2009, relativos ao ano de eclosão e de pico da crise norte-americana; e (iii) o período que abrange a eclosão da crise até os tempos atuais (1T/08-4T/12). A Tabela 3 ilustra os resultados dessa análise. 
Tabela 3 - Índices de Correlação Gap Crédito/PIB x Variação do PIB

\begin{tabular}{c|c|c}
\hline \multicolumn{3}{|c}{ Índice de Correlação } \\
\hline $1 \mathrm{~T} / 90-4 \mathrm{~T} / 12$ & $1 \mathrm{~T} / 08-4 \mathrm{~T} / 09$ & $1 \mathrm{~T} / 08-4 \mathrm{~T} / 12$ \\
\hline 0,34 & $-0,54$ & $-0,42$ \\
\hline
\end{tabular}

Fonte: Elaboração própria.

A tabela apresentada ilustra claramente o comportamento do coeficiente de correlação das variáveis. Em tempos de normalidade existe a tendência de que as variáveis possuam correlação positiva, ou seja, se o PIB varia positivamente o Gap também o faz. Entretanto, em períodos recessivos essa tendência se inverte abruptamente. As variáveis começam a apresentar um alto coeficiente de correlação negativo, o que aparenta ser extremamente prejudicial ao setor bancário e para a economia como um todo. Resumindo, a análise supracitada sugere que o padrão proposto pelo BCBS demonstra não ser eficiente no mercado brasileiro necessitando, dessa forma, de se buscar metodologias alternativas de cálculo.

Seguindo o proposto no artigo de Repullo e Saurina (2011), os Gráficos 6 e 7 ilustram o comportamento do crescimento do crédito agregado ao setor privado e o comparam com o crescimento do PIB brasileiro. Nesse contexto, torna-se importante ressaltar que a série foi dividida em dois períodos a fim de aumentar o poder de explicação gráfico.

Gráfico 6 - Série histórica crescimento do crédito x variação do PIB $(1 \mathrm{~T} / 90-2 \mathrm{~T} / 95)$

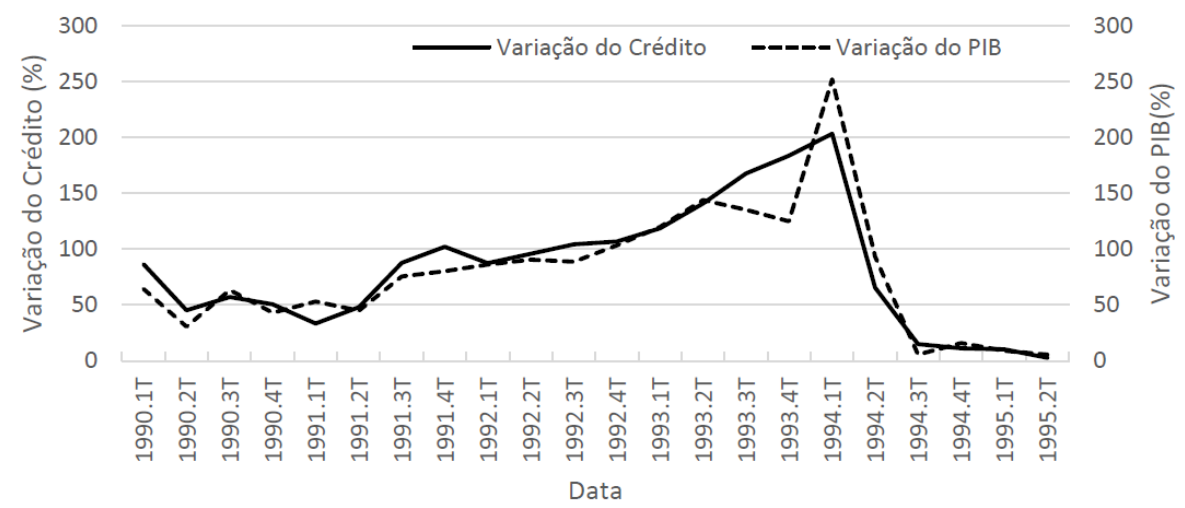

Fonte: Elaboração própria com base em dados do Banco Central do Brasil (2015b) e Ipeadata (2015). 
Gráfico 7 - Série histórica crescimento do crédito x variação do PIB $(3 \mathrm{~T} / 95-4 \mathrm{~T} / 12)$

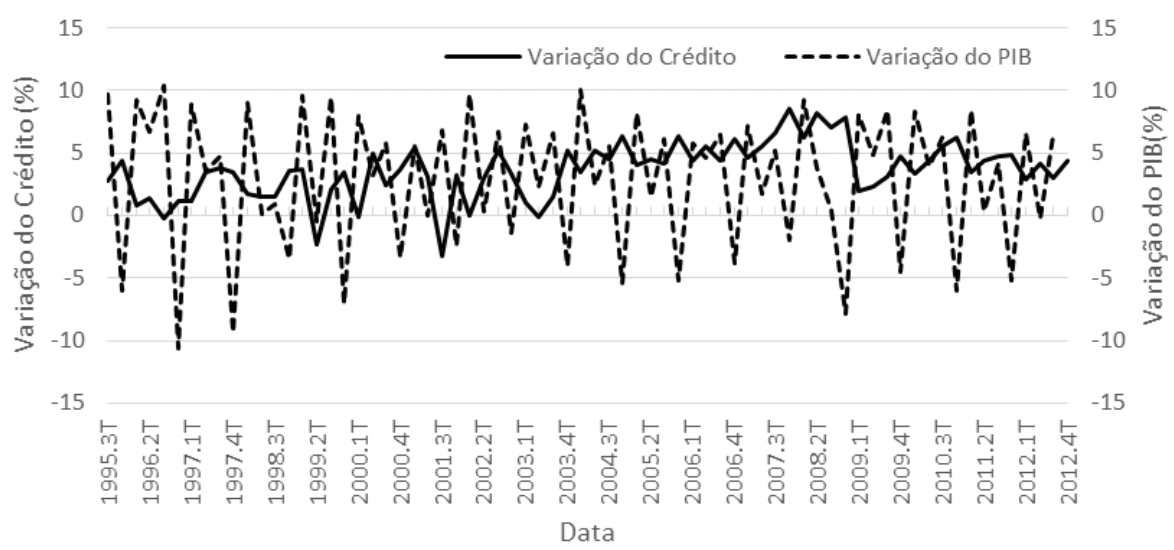

Fonte: Elaboração própria com base em dados do Banco Central do Brasil (2015b) e Ipeadata (2015).

Graficamente já é possível notar a maior aderência entre as duas séries. Dessa forma, infere-se que a utilização da variação do nível de crédito como ponto de partida para a tomada de decisões acerca do buffer contracíclico aparentemente é mais eficiente do que a utilização da metodologia proposta pelo BCBS, embora a correlação tenha diminuído no período mais recente. A Tabela 4 ilustra a correlação entre as duas séries analisadas e corrobora esta conclusão.

Tabela 4 - Índices de correlação crescimento do crédito $\mathrm{x}$ crescimento do PIB

\begin{tabular}{c|c|c}
\hline $1 \mathrm{~T} / 90-4 \mathrm{~T} / 12$ & $1 \mathrm{~T} / 08-4 \mathrm{~T} / 09$ & $1 \mathrm{~T} / 08-4 \mathrm{~T} / 12$ \\
\hline 0,97 & 0,21 & 0,35 \\
\hline
\end{tabular}

Fonte: Elaboração própria.

\section{Considerações Finais}

O Comitê de Basileia já reconheceu as deficiências do modelo apresentado e, por essa razão, acredita-se ser necessária uma melhor análise sobre qual seria a melhor referência para a tomada de decisões acerca do buffer contracíclico. O novo Acordo (Basileia III) foi implementado no Brasil a partir de outubro de 2013 e seu principal instrumento para conter a pró-ciclicidade, o buffer contracíclico, implantado segundo a metodologia proposta pelo BCBS, parece não demonstrar ser adequado para dar conta da pró-ciclicidade no setor bancário, inclusive do 
brasileiro, ainda que outros estudos - com outras metodológicas de avaliação - devam aprofundar esta avaliação. Dessa forma, torna-se fundamental avaliar cuidadosamente a adoção do buffer de capital contracíclico no setor bancário. A Basileia III pode ser considerada um avanço significativo em relação aos Acordos anteriores, mas ainda há muito a ser feito para garantir a solidez do setor e garantir a menor recorrência de crises financeiras. Tal tarefa, contudo, não é trivial, dada a tendência marcadamente pró-cíclica do setor bancário.

\section{Referências}

ASSOCIAÇÃO BRASILEIRA DAS ENTIDADES DOS MERCADOS FINANCEIRO E DE CAPITAIS. Basileia III no Brasil. 07/03/2013. Disponível em: < http://www.anbima.com.br/ informe_legislacao/2013_015.asp>. Acesso em: 15 set. 2014.

BANCO CENTRAL DO BRASIL. Perguntas e respostas sobre a implantação de Basileia III no Brasil. 2013. Disponível em: < http://www.bcb.gov.br/fis/supervisao/docs/perguntas_e_ respostas_basileia_iii.pdf>. Acesso em: 01 jul. 2014.

. Resolução $n^{\circ} 4.193$, de $1^{\circ}$ de março de 2013. Dispõe sobre apuração dos requerimentos mínimos de Patrimônio de Referência (PR), de Nível I e de Capital Principal e institui o Adicional de Capital Principal. Disponível em: <https://www.bcb.gov.br/pre/normativos/ busca/downloadNormativo.asp?arquivo=/Lists/Normativos/Attachments/49006/Res_4193_ v3_P.pdf >. Acesso em: 02 jun. 2015

. Sistema Gerenciador de Séries Temporais - v. 2.1. Disponível em: < https://www3.bcb.

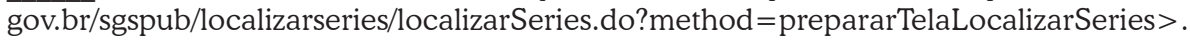
Acesso em: 21 jun. 2015

BANK FOR INTERNATIONAL SETTLEMENTS. Basel Committee on Banking Supervision. Basel III: a global regulatory framework for more resilient banks and banking system. Basel, Switzerland: BCBS, 2010a.

Basel Committee on Banking Supervision. Basel III: international framework for liquidity risk measurement, standards and monitoring. Basel, Switzerland: BCBS, 2010b.

. Basel Committee on Banking Supervision. Guidance for national authorities operating the countercyclical capital buffer. Basel, Switzerland: BCBS, 2010c.

CARVALHO, F. C.; KREGEL, J. Crise financeira e déficit democrático. Rio de Janeiro: IBASE, 2009.

CARVALHO, F. J. C. Inovação financeira e inovação prudencial: da regulação de liquidez aos acordos de Basiléia. In: SOBREIRA, R. Regulação financeira e bancária. São Paulo: Atlas, 2005 .

CLAESSENS, S. et al. Lessons and policy implications from the global financial crisis. Washington, DC: International Monetary Fund, Feb. 2010. (IMF Working Paper, n. 10/44).

DYMSKI, G. A. Is financial governance feasible in the neoliberal era? Reflections on post-war evolution of financial risk. June 2008. 16 p. Mimeo. 
FARHI, M. Crise financeira e reformas da supervisão e regulação. In: ENCONTRO INTERNACIONAL DA ASSOCIAÇÃO KEYNESIANA BRASILEIRA, 4., 2010, Rio de Janeiro. Anais... Rio de Janeiro: AKB, 2010.

FREITAS, M. C. P. A crise na Área do Euro. São Paulo: Fundap, 2011. p. 21-39. (Boletim de Economia, n. 10).

IPEADATA. Operações de crédito ao setor privado. Disponível em: < http://www.ipeadata.gov. br/Default.aspx>. Acesso em: 14 jun. 2015.

LEITE, K. V. B. S.; REIS, M. O acordo de capitais de Basileia III: mais do mesmo? In: ENCONTRO NACIONAL DE ECONOMIA, 39., 2011, Foz do Iguaçu. Anais... Foz do Iguaçu: Anpec, 2011.

MINSKY, H. Stabilizing an unstable economy. New Haven: Yale University Press, 1986.

PAULA, L. F.; ALVES JÚNIOR, A. J. Comportamento dos bancos, percepção de risco e margem de segurança no ciclo minskiano. Revista Análise Econômica, v. 21, n. 39, p. 137$162,2003$.

PEREIRA, M. S. A necessidade de reestruturação do sistema monetário internacional no póscrise financeira internacional. 2011. 91 f. Dissertação (Mestrado em Economia) - Programa de Pós-Graduação em Economia, Faculdade de Ciências Econômicas, Universidade Federal do Rio Grande do Sul, Porto Alegre, 2011.

REIS, M. O acordo de Basileia III e a pró-ciclicidade da regulação financeira. In: ENCONTRO NACIONAL DE ECONOMIA, 39., 2011, Foz do Iguaçu. Anais... Foz do Iguaçu: Anpec, 2011.

SADDI, J. A separação de funções dos bancos. Valor Econômico, 21 jun. 2010. Disponível em: <http://www.insper.edu.br/noticias/2010/06/23/separacao-de-funcoes-dos-bancos>. Acesso em: 15 dez. 2010.

SAURINA, J.; REPULLO, R. The countercyclical capital buffer of Basel III: a critical assessment. CENFI, Madrid, 2011. Disponível em: <ftp://ftp.cemfi.es/pdf/papers/repullo/RepulloSaurina\%20Final\%20R.pdf>. Acesso em: 10 jun. 2012.

SIDELSKY, R. Keynes: the return of the master. New York: Perseus, 2009.

SOBREIRA, R.; SILVA, T. Basileia III: longe de uma panaceia. In: MODENESI, A. et al. (Org.). Sistema financeiro e política econômica em uma era de instabilidade. Rio de Janeiro: Campus; Elsevier, 2012.

Recebido em: 07/12/2014. Aceito em: 26/04/2017. 